\title{
Nap, Hold, csillagok. A holdciklusok, napkitörések és mágneses viharok hatása az öngyilkosságokra
}

\author{
KMETTY ZOLTÁN ${ }^{1 *}$, BOZSONYI KÁROLY², \\ TOMASOVSZKY ÁLMOS ${ }^{3}$
}

\author{
${ }^{1}$ Eötvös Loránd Tudományegyetem, Társadalomtudományi Kar, \\ Szociológia Intézet, Budapest \\ ${ }^{2}$ Károli Gáspár Református Egyetem, Bölcsészettudományi Kar, \\ Társadalom- és Kommunikációtudományi Intézet, Budapest \\ ${ }^{3}$ Eötvös Loránd Tudományegyetem, Társadalomtudományi Kar, \\ Szociológia Doktori Iskola, Budapest
}

(Beérkezett: 2016. február 28.; elfogadva: 2016. július 11.)

Elméleti háttér: Az öngyilkosság-kutatások nagyon széles bázison vizsgálják a lehetséges rizikófaktorokat. Már az 1960-as években megjelentek olyan kutatások, amelyek a holdciklus öngyilkosságra gyakorolt lehetséges hatását próbálták meg feltárni. Az ezzel foglalkozó eddigi munkák felemás eredményt hoztak, de inkább arra mutattak, hogy a vizsgálatok középpontjába állított teliholdnak nincsen összefüggése a vizsgált kérdéssel. A különböző naptevékenységek (napkitörés) és ezek földi hatása (mágneses vihar) már kevésbé kutatott téma az öngyilkosság szempontjából. Az eddig eredmények viszont arra mutattak, hogy lehet összefüggés a jelenségek között, bár a csatolási mechanizmust már nem érintették ezek a munkák. Cél: A tanulmány célja megvizsgálni a holdciklus a napkitörések és a mágneses viharok együtt járását az öngyilkossági gyakoriságokkal. A tanulmányunkban felhasznált több mint 30 évnyi napi magyar öngyilkossági idősor lehetőséget teremt számunkra, hogy más munkákhoz képest sokkal részletesebben tudjuk körbejárni a kérdéskört. Módszerek: Tanulmányunkban az 1976 és 2010 közötti magyarországi öngyilkosságok számának napi normált számát (12784 nap) vizsgáljuk meg a holdciklusok, a napkitörések és a mágneses viharok aspektusából. Az öngyilkossági idősor esetében az évi lakosságszámra normált számok mellett a szezonálisan dekomponált idősorokat is vizsgáljuk (amelyekből a trend- és szezonhatásokat már eltávolítottuk). A holdciklus esetében elsősorban a teliholdra koncentrálunk, a napkitörés esetében külön vizsgáljuk az összes mérhető napkitörést és az erősebb $(M / X)$ napkitöréseket, míg a mágneses viharok esetében a közepes (Ap>39) és erős (Ap>100) mágneses viharokat különítjük el. Az egyes jelenségek által érintett és nem érintett napok átlagainak különbségét, Student-féle t-próbával, Welch-féle d-próbával, és ezek rang változataival vizsgáljuk. Eredmények: A telihold esetében az eredményeink arra mutatnak, hogy a jelenség nem függ össze az öngyilkossággal (csak a nők esetében mutatkozik egy gyenge kapcsolat, és az is csak a normált modellekben). A napkitörések és mágneses viharok vizsgálata már több szignifikáns öszszefüggést mutatott, mind a teljes, mind a női és férfi idősorban. Ezt azonban okozhatta a

\footnotetext{
* Levelező szerző: dr. Kmetty Zoltán, Eötvös Loránd Tudományegyetem, Társadalomtudományi Kar, Szociológia Intézet, 1117 Budapest, Pázmány Péter sétány 1/A. E-mail: zkmetty@tatk.elte.hu
} 
szezon komponens együttmozgása is, mivel a detrendelt és deszezonalizált öngyilkossági idősor esetében ezek az összefüggések már nem voltak azonosíthatók. Következtetések: A napkitörések és mágneses viharok esetében érdemes tovább folytatni a vizsgálatokat komplexebb statisztikai modellekkel is.

Kulcsszavak: öngyilkosság, telihold, napkitörés, mágneses vihar, idősor elemzés

\section{Bevezetés}

Az öngyilkosságnak számos rizikófaktorát azonosította már az ezzel foglalkozó szakirodalom. Az öngyilkosságok szezonális ingadozása (Partonen, Haukka, Nevanlinna, \& Lönnqvist, 2004; Zonda, Bozsonyi, \& Veres, 2005), egyes nagy társadalmi események - például Olimpia (Bozsonyi, Osvath, Fekete, \& Bálint, 2015), vagy politikai választások (Boor, 1981; Wasserman, 1983; Zonda, Kmetty, Lester, \& Tóth, 2015) , a különböző közösségi és családi ünnepek (Zonda, Bozsonyi, Kmetty, Veres, \& Lester, 2016) mind-mind befolyásolhatják az öngyilkosságok bekövetkezésének kockázatát. Tanulmányunkban ezt a lehetséges oksági kört két további iránnyal egészítjük ki, a Hold és a Nap potenciális hatásával.

A holdciklusok esetében a telihold mint toposz, fontos szerepet tölt be a mondavilágokban, az őrülettel, a magunkból kivetkőzéssel azonosítható. A nemzetközi szuicidológiai szakirodalom már az 1960-as évek végétől foglalkozik a holdciklus hatásának kérdésével. A Nap hatása, a napfoltok, napkitörések és közvetve a mágneses viharok egészségre gyakorolt hatása szintén kutatott kérdés, bár az ezzel kapcsolatos szakirodalmi elózmények jóval kisebb időtávot fognak csak át.

A Hold és a Nap hatásával ${ }^{1}$ két elméleti kiindulópont miatt érdemes foglalkozni. Az egyik egy biológiai faktor. Ebben az esetben azt feltételezzük, hogy a vizsgált jelenségek, olyan fiziológiai folyamatokat indítanak el az emberekben, amelyek valahogy befolyásolják az öngyilkosság elkövetésének valószínúségét. A másik szempont egy lehetséges társadalmi faktor. Ez a Nap esetében kevésbé releváns, de a holdciklus esetében már inkább evidens. Társadalmi hatás alatt azt értjük, hogy az emberek bizonyos jelenségekhez (például telihold) olyan gondolatkonstrukciókat párosítanak, amelyek esetlegesen magasabb szuicid rátához vezetnek. A születésnap például nyilvánvalóan nem okoz fiziológiai változást az ember életében, mégis megnöveli az öngyilkosság valószínúségét - főleg az idős nők esetében (Zonda és mtsai, 2016). Ilyen összefüggés esetleg elképzelhető a hold-

\footnotetext{
${ }^{1}$ Ebben a tanulmányban nem érintjük a napsütötte órák számának öngyilkosságra gyakorolt hatását (Petridou, Papadopoulos, Frangakis, Skalkidou, \& Trichopoulos, 2002). A napkitörésekre és az ezt követó mágneses viharokra koncentrálunk.
} 
ciklus esetében is. A telihold kapcsán számos mondai és mitikus elemmel találkozhatunk, a bulvármédia tele van asztrológiai és holdfázisokkal kapcsolatos írásokkal, amelyek aztán önbeteljesító jóslatként valóban hatást gyakorolhatnak a pszichés állapotra.

Tanulmányunk nem unikális olyan szempontból, hogy a kérdéssel már más szerzők is foglalkoztak korábban (ezt a következő fejezetben járjuk körbe). Munkánk olyan szempontból mégis egyedi, hogy több mint 30 év öngyilkossági statisztikáit tudjuk vizsgálni, ráadásul napi szinten, és egy olyan országban - Magyarországon - ahol világviszonylatban is magasnak számít a szuicid ráta. Utóbbi (önmagában szomorú) momentum adatelemzési szempontból viszonylag sok lehetőséget hagy számunkra, ami által a korábbi, hasonló tematikájú tanulmányoktól eltérően mélyebbre tudunk ásni, megbízhatóbb és érvényesebb eredményekre tudunk eljutni.

\section{Szakirodalmi elózmények}

A hatvanas évektól napjainkig számos nemzetközi tanulmány foglalkozott a holdfázisok és az öngyilkosságok közötti összefüggés vizsgálatával. Arra a kérdésre, hogy a szinodikus (újholdtól teliholdig tartó), vagy az anomalisztikus holdhónap (legkisebbtől a legnagyobb Hold-Föld távolságig tartó időszak) bizonyos periódusaiban eltér-e az öngyilkosságok, vagy öngyilkossági kísérletek gyakorisága, a kutatók többsége $\chi^{2}$-próbákon alapuló módszertan segítségével kereste a választ.

Az egyik legkorábbi cikk szerzője a Texasban 1961 és 1963 között történt öngyilkossági kísérleteket vizsgálta a telihold és újhold, valamint a földhöz közeli és földtől távoli fázisok körüli kéthetes periódusokban (Pokorny, 1964). Bár a tanulmányban nem szerepelnek a statisztikai próbák eredményei, a táblázatok és egy későbbi cikk szerzőinek számításai alapján nem volt szignifikáns eltérés a vizsgált félperiódusok között az öngyilkosságok gyakorisága szerint (Martin, Kelly, \& Saklofske, 1992).

Egy másik, szintén a hatvanas években készült tanulmány az Egyesült Államokbeli Erie megyéből származó, 1964 és 1968 közötti időszakot felölelő adatok elemzése alapján hasonló eredményre jutott. Bár a tanulmány szerint 1967-ben a nők esetében szignifikánsan több öngyilkossági kísérlet történt a telihold körüli egyhetes időszakokban, a többi évben nem volt kimutatható az összefüggés. Sót, az előzetes várakozásokkal szemben a teliholdat megelőző és az azt követó pár napban kevesebb öngyilkossági kísérlet történt, mint a fennmaradó időszakban (Lester, Brockopp, \& Priebe, 1969).

A telihold és az öngyilkosság nők körében megfigyelhető összefüggését Taylor és Diespecker (1972) is kimutatta. Az ausztráliai Illawarra régióból származó, 1971-es adatok szerint ugyanis esetükben a holdfázis első negye- 
dében, valamint teliholdkor a vártnál gyakoribbak voltak az öngyilkossági kísérletek. Az eredményekkel kapcsolatban fontos azonban megjegyezni, hogy a kutatók rendkívül kevés esettel (84 fóvel) dolgoztak, és egy másik, nagyobb méretú mintán az eredményeket nem sikerült más kutatóknak reprodukálniuk (Martin és mtsai, 1992).

Egy néhány évvel későbbi tanulmány szerzői az USA-beli Cuyahoga megyéból származó adatok alapján arra a következtetésre jutottak, hogy a fentiekkel szemben újhold idején történnek a vártnál nagyobb számban öngyilkosságok. Az öngyilkosságok száma teliholdkor és a többi napon nem tért el szignifikánsan a véletlentól (Jones \& Jones, 1977).

A kilencvenes évek elején is született két olyan tanulmány, amelyben a kutatók $\chi^{2}$-próbákal vizsgálták a holdfázisok és az öngyilkosság kapcsolatát, de egyik tanulmány sem talált szignifikáns összefüggést (Mathew, Lindesay, Shanmuganathan, \& Eapen, 1991; Maldonado \& Kraus, 1991).

A fentiekből látható, hogy az 1960-as és 1990-es évek között az általunk is vizsgált kérdéskörrel kapcsolatos, viszonylag egyszerú módszertanokkal operáló munkák nem, vagy csak néhány esetben mutattak ki összefüggést az öngyilkosságok száma és a holdfázisok között. Erre utal Martin és munkatársainak (1992) tanulmánya is, amelyben összefoglalnak 11 öngyilkossággal és 12 öngyilkossági kísérletekkel kapcsolatos tudományos munkát, amelyek közül csak néhány vizsgálat jutott arra a megállapításra, hogy a fentiekben leírt összefüggés fennáll. Utóbbi eredmények azonban más mintákon nem voltak reprodukálhatók (pl. Taylor \& Diespecker, 1972).

Rotton, Kelly és Frey (1983) a reprodukálhatóságon kívül a módszertani felületesség miatt is bírálták a hatvanas, hetvenes, illetve a nyolcvanas évek elején született tanulmányokat. Az öngyilkosságok és a holdfázisok kapcsolatát vizsgáló egyes tanulmányok módszertanával kapcsolatos legfontosabb probléma szerintük az, hogy általában súlyosan sérült a vizsgált események (egyes öngyilkosságok) egymástól való függetlenségének kritériuma (ami a $\chi^{2}$-próba egyik alkalmazási feltétele). Megoldásként az idősor elemzés eszköztárának és ARIMA modellek alkalmazását javasolták. A szerzők példaként említenek egy 1979-es tanulmányt (Michelson, Wilson, \& Michelson, 1979), amelyben egy Fort Lauderdale és egy Broward megyei krízisközpontba beérkező, öngyilkossági kísérletekkel kapcsolatos hívások számát és a holdciklusok kapcsolatát vizsgálták. A kutatók arra a kérdésre keresték a választ, hogy telihold idején több öngyilkossági kísérlet történik-e, ennek megfelelően a szinodikus holdciklusokra egy szinusz-függvényt illesztettek, ${ }^{2}$ és ennek a függvények, valamint a krízisközpontba érkező hívások idősorá-

2 A függvény a telihold időpontjában 1-es, újhold idején -1-es értéket vett fel, hullámhossza megegyezett a szinodikus holdciklus hosszával (azaz $\lambda=29,53$ nappal). 
nak korrelációját vizsgálták. Ez a korreláció sem újhold, sem telihold idején, sem a fennmaradó időszakban nem volt szignifikáns (Rotton és mtsai, 1983).

A szerzők az öngyilkossági kísérletek periodicitását is megvizsgálták a bejövő hívások idősorának spektrál-felbontásával (Fourier-transzformáció), de a kapott periódusok sem a szinodikus (29,53 nap), sem az anomalisztikus (27,55 nap) ciklussal nem csengtek egybe.

A kérdéskört a 2000-es években is több tanulmányban vizsgálták. Biermann és munkatársai (2005) 1998 és 2003 közötti német populációs adatokon elemezték az újhold és a telihold körüli 5 napos időszakok és az öngyilkosságok számának összefüggését nem, kor és módszer (violens - nem violens) szerinti bontásban. A nagy adathalmazból származó mintákon azonban sem az újholdnak, sem a teliholdnak nem volt szignifikáns hatása az öngyilkosságok számára, csupán az volt megállapítható, hogy a(z életkor mediánjánál) fiatalabb áldozatok az újhold körüli 5 napos időszakban kisebb gyakorisággal választottak nem violens módszereket (Biermann és mtsai, 2005).

Voracek és munkatársai (2008) több mint 65 ezer ausztriai öngyilkosságot elemeztek holdciklusok szerinti bontásban, és a teljes adatsoron nem találtak szignifikáns összefüggést. Az egyes almintákon is csak szórványosan és mindenféle jól azonosítható mintát nélkülözve bukkantak összefüggésekre a szerzők. Erre támaszkodva azt állapították meg, hogy ha időnként lehet is találni összefüggéseket, az legvalószínúbben az első fajú hibának köszönhetó.

Belleville és munkatársai (2013) két kanadai kórház sürgősségi osztályán vizsgálták többek között az öngyilkossági kísérletek holdciklus szerinti előfordulását. Az ő eredményeik is azt mutatták, hogy a holdciklusok nem függnek össze a vizsgált jelenséggel.

A napfolttevékenység és az erőszakos cselekmények, köztük az öngyilkosság kapcsolatának elemzésével kevesebb tudományos munkában találkozhatunk. Az alábbiakban két tanulmány módszereit és eredményeit mutatjuk be.

Berk és munkatársai (2006) az Ausztráliában 1968. január és 2002. augusztus között történt öngyilkosságokat vizsgálták. Munkájuk során kiszámolták az esetek napi átlagos számát éves bontásban, azokra a napokra, amikor nem mértek számottevő napfolttevékenység következében kialakult geomágneses viharokat (Ap-index $\leq 100)$, és ezt varianciaanalízis segítségével összehasonlították azoknak a napoknak az átlagaival, amelyeken a viharok napi aktivitása meghaladta az Ap-index küszöbértékként választott 100-as értékét. ${ }^{3}$ Az elemzéseket nemek szerinti bontásban, minden évszakra

\footnotetext{
${ }^{3}$ A kutatók (az elemszám-problémák miatt, valamint egy időben elnyúló hatást feltételezve) úgy is elvégezték az elemzéseket, hogy nemcsak azokat a napokat tekintették a napkitörés szempontjából relevánsnak, amelyeken az Ap-index értéke 100 feletti volt, hanem az ezek utáni 2 és 4 napot is.
} 
külön elvégezték. Ez utóbbit az indokolja, hogy korábbi tanulmányok és számításaik szerint az öngyilkosságok számára az évszak is hatással van, ráadásul ez nemek szerint eltér. ${ }^{4}$ Azokon az őszi napokon, amikor erős geomágneses viharokat mértek, a nők által elkövetett öngyilkosságok átlagos száma magasabb volt $(1,86)$, mint a többi napon $(1,27)$, és az ilyen napokkal kezdődő háromnapos időszakok vizsgálata ugyanerre az eredményre vezetett (átlagosan 1,61 és 1,27 eset). A hosszabb (négynapos) időszakokkal vizsgálva, a többi évszakban és a férfiak esetében nem volt szignifikáns az összefüggés (Berk, Dodd, \& Henry, 2006).

Egy másik tanulmányban Grigoryev, Rozanov, Vaiserman és Vladimirskiy (2009) arra a kérdésre keresték a választ, hogy milyen összefüggésben állnak az Izraelben, Irakban és Afganisztánban 1994 és 2008 között történt terrortámadások a különböző napfizikai folyamatokkal. Bár a támadások és a napfolttevékenység idősorában nem találtak összefüggést, az 1062 támadás előtti és utáni pár napban szignifikáns napfizikai változások történtek. A terrortámadások napján, és egy nappal később szignifikáns mértékben növekedett a geomágneses aktivitás a (támadás körüli 5-5 napos időszakon belüli) többi naphoz képest (C9-index standardizált változásai). Ezen kívül a bolygóközi mágneses tér polaritása szignifikáns változást mutatott a támadások előtt egy nappal. A szerzők szerint ez utalhat arra, hogy a terrortámadások tervének véglegesítésében lehet szerepe a napfolttevékenységeknek, illetve ezek biológiai és fiziológiai hatásainak.

\section{Módszertan}

Tanulmányunkban az 1976 és 2010 közötti magyarországi öngyilkosságok számának napi eloszlását (12784 nap) vizsgáljuk meg a holdciklusok, a napkitörések és a mágneses viharok aspektusából. Az öngyilkossággal kapcsolatos napi adatsort a Központi Statisztikai Hivatal (KSH) bocsájtotta rendelkezésünkre. Az összes elkövetett napi öngyilkosság mellett (130 860 eset) külön vizsgáltuk a női (36 084 eset) és férfi (94 476 eset) előfordulásokat, és a violens (77 169) és nem violens (29 628) elkövetési formákat. Az elkövetés módjára csak 2002-ig állt rendelkezésünkre adat, ezért az elkövetési forma metszetében vizsgált idősorok 8 évvel kevesebb adatot tartalmaznak csak (9 862 nap). Elemzésünkben nem a nyers öngyilkossági számokkal dolgoz-

\footnotetext{
4 A nők és a férfiak esetében is tavasszal volt átlagosan a legtöbb öngyilkosság. A nők körében nyáron, a férfiaknál ősszel fordult elő átlagosan kevesebb ilyen eset, évszakok szerinti szignifikáns különbség azonban csak a nók esetében látható. Meg kell ugyanakkor jegyeznünk, hogy ez a szezonális mintázat jelentősen eltér az északi félgömbön több tucat országban igazolt nyáritavaszi csúcs, ôszi-téli mélypont mintázattól, amely férfiakra és nőkre egyaránt igaz.
} 
tunk, hanem a lakosságszámra normált értékekkel (1 napon 1 millió lakosra hány öngyilkosság jut). A normálást az év minden napjára a január 1-jei népességgel hajtottuk végre.

A magyarországi öngyilkossággal kapcsolatos elemzések (Zonda, \& Bozsonyi, Veres 2005; Zonda 2006) többször körbejárták már, hogy mely tényezők befolyásolják az adatsor hullámzását. Az 1980-as évek végétől a 2000-es évek közepéig 1-2 rövidebb stabil periódus mellett szinte folyamatosan csökkent az öngyilkosságok száma, majd a 2005-es évek közepétól inkább egy stagnálás volt rá jellemző (1. ábra).

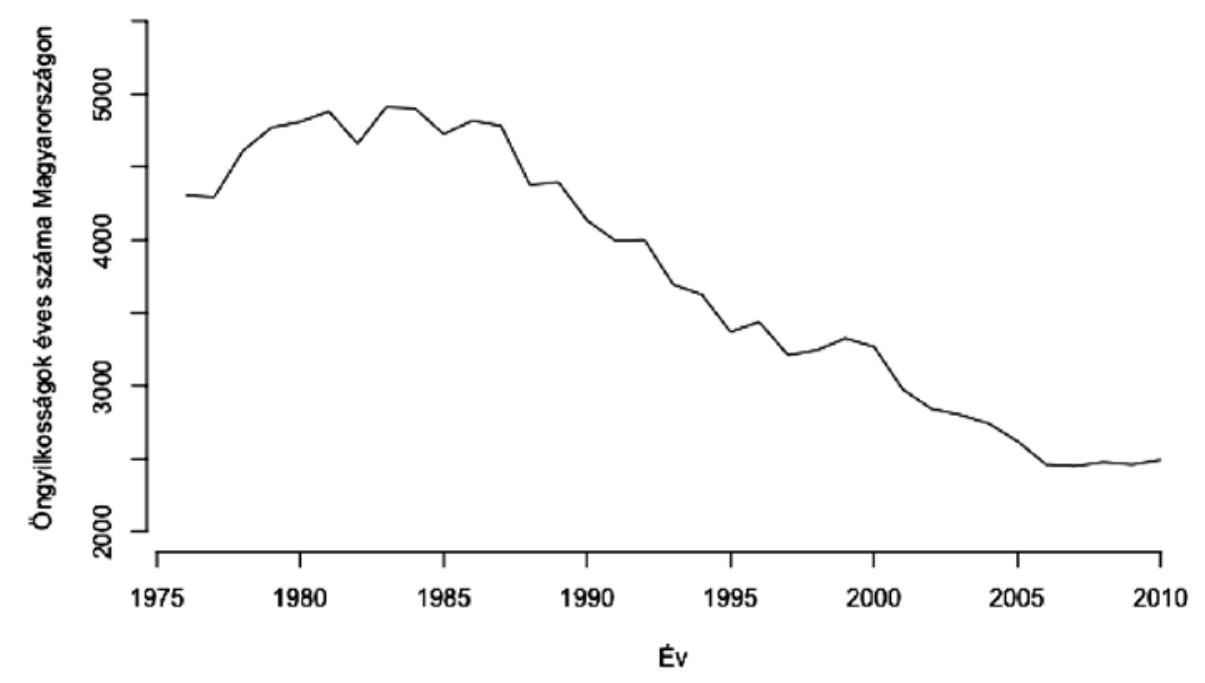

1. ábra. Az öngyilkosságok éves számának alakulása 1976 és 2010 között (KSH adatok alapján saját szerkesztés)

A jól azonosítható trend mellett több szezonkomponens is jellemző az öngyilkossági idősorokra, mind havi (nyáron magas, télen alacsony, lásd 2.b ábra), mind héten belüli (hét elején magas, hét végén alacsony, lásd 2.a ábra) ciklikusság megfigyelhető. Az idősorokon azonosítható trend- és szezonkomponensek torzíthatják azokat az elemzéseket, amelyeket olyan változók mentén végzünk, amelyek szintén hasonló trend- vagy szezonkomponenssel rendelkeznek. Ahogy a későbbiekben látni fogjuk a holdciklusok és a napkitörések esetében ez a probléma nem (vagy csak korlátozottan) jelentkezik. Ennek ellenére a szórások csökkentése érdekében a normált idősorok mellett kiszámoltuk ezek detrendelt és deszezonalizált változatait is. ${ }^{5}$

\footnotetext{
5 Technikailag ez a következőképpen történt: A napi normált idősort havi szintre aggregáltuk, és ezen a havi idősoron végeztünk el egy szezonális dekompozíciót 12 hosszúságú szezonpara-
} 
Tanulmányunkban mind a két idősort (normált, detrendelt és deszezonalizált) vizsgáljuk.

2.a

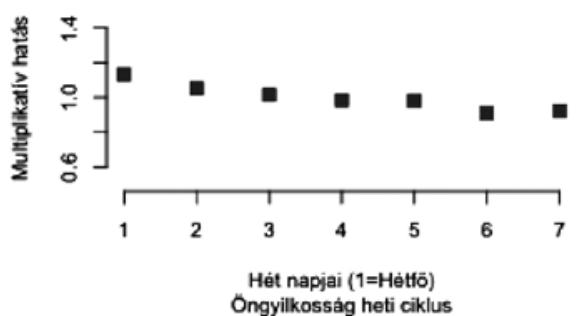

2.c

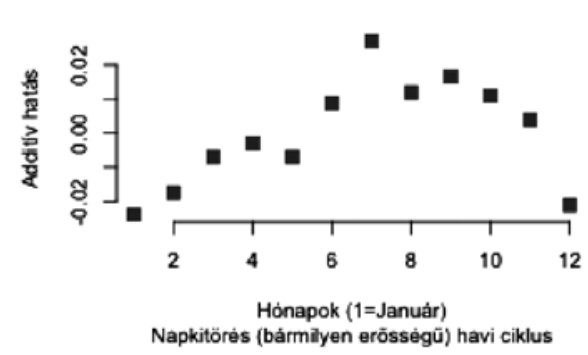

2.b

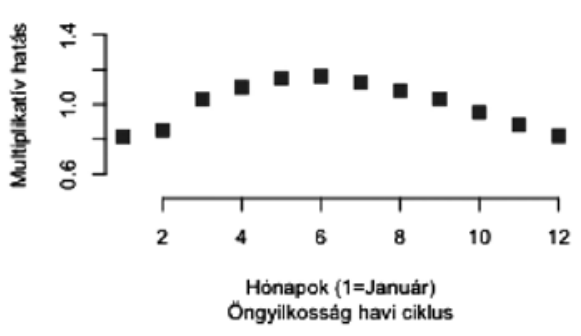

2.d

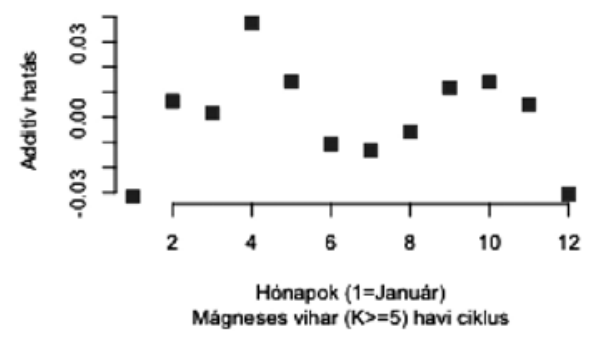

2. ábra. A vizsgált idősorok szezon komponensei ${ }^{6}$

2.a Öngyilkosság heti ciklus, szezonális dekompozíció, multiplikatív modell

2.b Öngyilkosság havi ciklus, szezonális dekompozíció, multiplikatív modell

2.c Napkitörés (bármilyen erősségú) havi ciklus, szezonális dekompozíció, additív modell

2.d Mágneses vihar $(K \geq 5)$ havi ciklus, szezonális dekompozíció, additív modell

A holdciklus esetében a témánk szempontjából a teliholdat és az újholdat tekintjük kitüntetett jelentőségúnek. Egy holdciklus 29,53 napig tart, ami azt jelenti, hogy folyamatosan vándorol a standard naptárhoz képest, hogy mi-

méterrel, multiplikatív módszerrel. Az így kapott trend- és szezonkomponenst leválasztottuk a napi idősorunkról, majd a napi tisztított idósoron is elvégeztünk egy szezonális dekompozíciót, 7 hosszúságú szezon paraméterrel, szintén multiplikatív módszerrel. Az így dekomponált idősor már nem tartalmazott se trendet, se szezont (se havit, se hetit). Értelemszerúen a teljes idősor mellett a férfiak, a nók valamint a violens és nem violens elkövetők esetében is ugyanezt a módszert követtük.

6 Az öngyilkossági idősor heteroszkedasztikus volt, ezért multiplikatív dekompozíciós eljárást kellett választanunk az esetében, a napkitörések és mágneses viharos esetében viszont az additív modell illeszkedett jobban. 
kor van telihold. Előbbiből következik, hogy az öngyilkosság és holdhónap ciklusa teljesen eltér egymástól. 1976 és 2010 között 433 olyan nap volt, amikor telihold volt és ugyanennyi nap, amikor újhold. Tanulmányunkban egyrészról ezeket a kitüntetett napokat vizsgáljuk az öngyilkossági számok alakulása szempontjából, másrészról a korábbi szakirodalmi munkákhoz hasonlóan ennek egy bővebb változatát is, amikor a telihold előtti és utáni 2-2 napot is bevesszük a vizsgált idótávba.

A holdciklussal ellentétben a napkitörések előfordulása nem követ pontos ciklust. A napkitöréseket 5 osztályba sorolják, ezek a következők: A/B / C/M/X (Kildahl, 1980). Az „A" osztály a leggyengébb napkitörés, az X pedig a legerősebb, az egyes osztályok között 10-szeres szorzó van erősség tekintetében. A napkitörés nem feltétlen csak 1 napig tart, akár több napig is elhúzódhat. A napkitörések esetében az adatok forrása az amerikai Marshall Space Flight Center (MSFC) volt. ${ }^{7}$ Az 1976 és 2010 közötti időszakban az MSFC adatbázis alapján 223 napkitörést lehetett azonosítani, ebból 78 volt M erősségú és $12 \mathrm{X}$ erősségú. Tanulmányunkban több bontásban is vizsgáltuk a napkitörések hatását:

- Napkitörés teljes időszaka, bármilyen erősség (479 nap)

- Napkitörés teljes időszaka, M és X erősség (223 nap)

- Napkitörésnek csak a csúcsnapja, bármilyen erôsség (166 nap)

- Napkitörésnek csak a csúcsnapja, M és X erősség (90 nap)

Ahogy a fenti bekezdésben jeleztük, a napkitörések esetében nem lehet pontos ciklust azonosítani, azonban a napkitörések gyakorisága mutat öszszefüggést a napciklussal. A napciklus átlagosan 11 évig tart, és a ciklus elején figyelhető meg egy fokozódó aktivitása a napnak. A napkitörések akkor válnak gyakoribbá, amikor a naptevékenység erőssé válik, ez inkább már a ciklus második részében tapasztalható. Ha három részre bontjuk a napciklust, az első három évet véve a napciklus elejének, az utolsó három évet a ciklus végégnek és a köztes éveket pedig a ciklus közepének, akkor az mondható el, hogy a vizsgált periódusban megfigyelhető négy napciklus esetében a középsó periódusban szignifikánsan több volt a napkitörés, fóleg az M és X erősségúek. A napkitörések esetében lehetett egy havi szezonkomponenst is azonosítani. Ha a gyengébb erósségú napkitöréseket is vizsgáljuk, és nem csak a maximum napokra koncentrálunk, hanem a teljes

\footnotetext{
7 Az adatokat 1874 és 1976 között a Royal Observatory Greenwich (ROG), 1976-tól pedig az Egyesült Államok légiereje (United States Air Force - USAF) gyújtötte és rendszerezte. Utóbbi az USA-beli National Oceanic and Atmospheric Adminstration-nel (NOAA) kiegészülve napjainkig gyújt adatokat a napfolt-tevékenységról, amelyek az MSFC egykori munkatársa, Dr. David Hathaway jóvoltából az alábbi weboldalon érhetők el: http://solarscience.msfc.nasa.gov/ greenwch.shtml
} 
érintett időszakra, akkor egy nyári csúcs és egy téli lefele trend azonosítható (2.c ábra), de ha csak az M és X erósségú kitörésekre koncentrálunk, akkor ez már nem figyelhetó meg. Nyáron több a gyengébb, de hosszabban tartó napkitörés (leginkább C erósségú). Mivel ez a típusú szezonhatás egybevág az öngyilkosság idősor havi szezonkomponensével, ezért ebben a bontásban kiemelten fontos, hogy a deszezonalizált és detrendelt öngyilkossági idősort használjuk fel az elemzésben.

A mágneses viharok a nagyobb napkitöréseket követik. A mágneses zavarokat a K-index alapján lehet többek között osztályozni (Bartels, Heck, \& Johnston, 1939). A 0-9 közötti skálán az 5-ös erősségtől beszélhetünk mágneses viharról. A tanulmányunkban felhasznált adatok forrása a „World Data Center for Geomagnetism" Kyotoi adatbank volt, ahol 1932-tól elérhetók mágneses viharokra vonatkozó adatok. Ebben az adatbázisban 1996-ig a Gottingeni egyetem Geofizikai Intézetétől származnak az adatok, 1997-től pedig a GeoForschungsZentrum (GFZ) Postdami Intézettől. A háromóránkénti Ap-index adatokat napi szinten átlagoltuk, és ha ez az átlag meghaladta a 39-et (ez feleltethető meg az 5-ös erősségú K-értéknek), akkor az adott napot a mágneses vihart méró változónkon 1-re kódoltuk, ha ennél kisebb érték volt, akkor 0-ra. A vizsgált időszakban 588 olyan nap volt, ahol ez alapján a számítás alapján volt valamilyen erősségú mágneses vihar. Külön elemeztük azokat a napokat is, ahol az Ap-index 100 feletti értéket vett fel (ez 6 feletti K-indexnek felel meg). Ez alapján különösen intenzív mágneses vihar a teljes időperiódusban 46 nap volt azonosítható. Annak érdekében, hogy tesztelni tudjuk a mágneses viharok elnyújtott hatását is, végeztünk olyan számításokat is, ahol +2 napot hozzáadtunk a mágneses vihar lecsengéséhez. A mágneses viharok esetében is volt szezonalitás, januárban és decemberben kevesebb napot érintett átlagban a mágneses vihar, amelynek a csúcsa áprilisban volt (2.d ábra).

Mivel mind a holdciklust, mind a napkitöréseket mind a mágneses viharokat kétértékú binomiális változókkal mérjük a tanulmányunkban, ezért egységes elemzési módszertant használtunk. Minden bontás esetében első lépésben egy F-próba segítségével megállapítottuk, hogy a napi átlagos öngyilkosságok számának szórásai heterogének vagy homogének-e, majd homoszkedasztikus adatstruktúra esetében független mintás Student-féle t-próbát alkalmaztunk, heteroszkedasztikus adatok esetében pedig Welchféle d-próbát. A normalitás is előfeltétele a t-próba alkalmazásának, ami esetünkben nem teljesül. Ugyanakkor a t-próba robosztus a normalitás megsértésére, ha az eloszlás nem ferde (Hunyadi-Vita, 2002). Így a t-próba alkalmazása mellett dönthettünk. Hipotéziseinket ugyanakkor egy robosztusabb próbával, rang t-próbával is teszteltük. Azokat az eseteket, ahol a rang t-próba eltéró eredményt adott, külön jelezzük. Az elemzéseket az SPSS 21. statisztikai programmal végeztük el. 


\section{Eredmények}

\subsection{Holdciklus}

A holdciklus vizsgálatakor első lépésben csak a telihold napját vizsgáltuk. A 10 vizsgált modellből mindössze egy esetben találtunk szignifikáns összefüggést, ez pedig a nők esetében volt (1. táblázat). Az irány viszont nem a várakozásainknak megfelelően alakult, mivel a telihold napján átlagosan kevesebb volt a nói öngyilkos, mint a holdciklus többi napján. Az összefüggés 5 százalékos szinten volt szignifikáns, 1 százalékos szinten már nem (a rangpróbás futtatásban szintén szignifikáns volt az összefüggés p=0,029 szinten). Az eredmények érvényessége kapcsán jelzésértékú, hogy a nők esetében csak az alap normált mutató „múködött”, a detrendelt és deszezonalizált mutató már nem volt szignifikáns. Bár a nők estében szignifikáns az eredmény, meg kell jegyezni, hogy az effektus mérete nem tekinthetó relevánsnak. Mint látható a teliholdas napokon az országban durván két tizeddel kevesebb női öngyilkosság van, mint más napokon (2,62 vs. 2,83 naponta). Természetesen azt sem tudhatjuk, hogy a teliholdas napokon be nem következett szuicid események bekövetkeznek-e más napokon.

Az összefüggést megvizsgáltuk egy olyan bontásban is, ahol a teliholdhoz hozzászámoltuk a két megelőző és két azt követő napot is. Ennek kapcsán az volt a feltevésünk, hogy a teliholdnak időben elnyújtott hatása is lehet. Az ezt vizsgáló elemzések, azonban egy bontásban sem találtak szignifikáns összefüggést (lásd Függelék, F1. táblázat). A rang próbás futtatás a nők esetében azonban itt is szignifikáns összefüggést mutatott $(p=0,014)$, megegyező előjellel, mint korábban.

Olyan számításokat is végeztünk, ahol 3 időszakra bontottuk az adatsort, újholdra, teliholdra és köztes időszakra. A 3 időszak közötti különbséget egyszempontos varianciaanalízissel (ANOVA) teszteltük. Egyik vizsgált bontásban sem találtunk szignifikáns különbséget a 3 időszak mentén. Az eredményeket a Függelék F2. táblázatában részletezzük.

\subsection{Napkitörés}

A napkitörések esetében négy különböző szcenáriót is teszteltünk. Azok a modellek, ahol az összes napkitörést vizsgáltuk egy esetben sem mutattak szignifikáns összefüggést az öngyilkossági mutatókkal (lásd Függelék, F3. és F4. táblázat). A legerősebb M és X intenzitású napkitörések esetében azonban több szignifikáns összefüggés is detektálható volt, amikor a teljes napkitörési ciklust vizsgáltuk (2. táblázat). A normált adatokban a teljes öngyilkossági arányszám és a női arányszám is 1 százalékos szinten volt szignifikáns, a férfiak arányszáma pedig 5 százalékos szignifikancia szinten. 
1. táblázat. Az öngyilkossági mutatók alakulása a telihold napján - t-próba

\begin{tabular}{|c|c|c|c|c|c|c|}
\hline & & $\begin{array}{l}\text { Eset- } \\
\text { szám }\end{array}$ & Átlag & $\begin{array}{l}\text { Stan- } \\
\text { dard } \\
\text { hiba }\end{array}$ & t-érték & $\mathrm{p}$ \\
\hline \multirow{2}{*}{$\begin{array}{l}\text { Öngyilkosság aránya } \\
\text { (normált) }\end{array}$} & Nincs telihold & 12351 & 0,983 & 0,004 & 1,086 & 0,277 \\
\hline & Telihold & 433 & 0,961 & 0,020 & & \\
\hline \multirow{2}{*}{$\begin{array}{l}\text { Férfi öngyilkosság } \\
\text { aránya (normált) }\end{array}$} & Nincs telihold & 12351 & 1,482 & 0,006 & 0,139 & 0,889 \\
\hline & Telihold & 433 & 1,478 & 0,033 & & \\
\hline \multirow{2}{*}{$\begin{array}{l}\text { Női öngyilkosság } \\
\text { aránya (normált) }\end{array}$} & Nincs telihold & 12351 & 0,522 & 0,003 & 2,15 & $0,032^{*}$ \\
\hline & Telihold & 433 & 0,484 & 0,016 & & \\
\hline \multirow{2}{*}{$\begin{array}{l}\text { Violens öngyilkosság } \\
\text { aránya (normált) }\end{array}$} & Nincs telihold & 9528 & 0,748 & 0,003 & 0,851 & 0,395 \\
\hline & Telihold & 334 & 0,733 & 0,018 & & \\
\hline \multirow{2}{*}{$\begin{array}{l}\text { Nem violens } \\
\text { öngyilkosság aránya } \\
\text { (normált) }\end{array}$} & Nincs telihold & 9528 & 0,286 & 0,002 & 1 & 0,317 \\
\hline & Telihold & 334 & 0,275 & 0,011 & & \\
\hline \multirow{2}{*}{$\begin{array}{l}\text { Öngyilkosság aránya } \\
\text { (detrendelt és } \\
\text { deszezonalizált) }\end{array}$} & Nincs telihold & 12351 & 0,989 & 0,002 & 1,234 & 0,217 \\
\hline & Telihold & 433 & 0,974 & 0,013 & & \\
\hline \multirow{2}{*}{$\begin{array}{l}\text { Férfi öngyilkosság } \\
\text { aránya (detrendelt és } \\
\text { deszezonalizált) }\end{array}$} & Nincs telihold & 12351 & 0,985 & 0,003 & 0,218 & 0,828 \\
\hline & Telihold & 433 & 0,982 & 0,015 & & \\
\hline \multirow{2}{*}{$\begin{array}{l}\text { Női öngyilkosság } \\
\text { aránya (detrendelt és } \\
\text { deszezonalizált) }\end{array}$} & Nincs telihold & 12347 & 0,955 & 0,005 & 1,782 & 0,075 \\
\hline & Telihold & 432 & 0,911 & 0,024 & & \\
\hline \multirow{2}{*}{$\begin{array}{l}\text { Violens öngyilkosság } \\
\text { aránya (detrendelt és } \\
\text { deszezonalizált) }\end{array}$} & Nincs telihold & 9528 & 0,986 & 0,003 & 0,601 & 0,548 \\
\hline & Telihold & 334 & 0,976 & 0,017 & & \\
\hline \multirow{2}{*}{$\begin{array}{l}\text { Nem violens } \\
\text { öngyilkosság aránya } \\
\text { (detrendelt és } \\
\text { deszezonalizált) }\end{array}$} & Nincs telihold & 9523 & 0,955 & 0,005 & 0,923 & 0,356 \\
\hline & Telihold & 334 & 0,929 & 0,027 & & \\
\hline
\end{tabular}

Megjegyzés: * p<0,05. A szignifikáns eredményeket félkövér betúvel emeltük ki.

Mind a három dimenzióban a napkitörések alatt magasabb volt az öngyilkosságok száma. A teljes idósor és a női adatok esetében a rang változat is szignifikánsnak bizonyult ( $\mathrm{p}=0,007$, illetve $\mathrm{p}=0,024)$. Az eredményeket árnyalja viszont, hogy a detrendelt és deszezonalizált idősorok esetében már nem volt szignifikáns az összefüggés. Mivel mind a napkitörések mind az öngyilkosságok mutatnak szezonális mintázatot, a nem deszezonalizált 
adatok közti összefüggések valószínúleg a szezonális-, illetve trendkomponensek hatásainak tudhatóak be. Arra a kérdésre, hogy van-e a naptevékenységnek tényleges együtt járása az öngyilkosságokkal, csak egy szofisztikáltabb statisztikai elemzés alapján adhatunk majd választ.

2. táblázat. Az öngyilkossági mutatók alakulása a napkitörésekkor (teljes napkitörés ciklus, M és X erősség) - t-próba

\begin{tabular}{|c|c|c|c|c|c|c|}
\hline & & $\begin{array}{l}\text { Eset- } \\
\text { szám }\end{array}$ & Átlag & $\begin{array}{l}\text { Stan- } \\
\text { dard } \\
\text { hiba }\end{array}$ & t-érték & $\mathrm{p}$ \\
\hline \multirow{2}{*}{$\begin{array}{l}\text { Öngyilkosság } \\
\text { aránya (normált) }\end{array}$} & Nincs napkitörés & 12618 & 0,981 & 0,004 & $-2,905$ & $0,004^{* *}$ \\
\hline & Napkitörés & 166 & 1,075 & 0,032 & & \\
\hline \multirow{2}{*}{$\begin{array}{l}\text { Férfi öngyilkosság } \\
\text { aránya (normált) }\end{array}$} & Nincs napkitörés & 12618 & 1,481 & 0,006 & $-2,096$ & $0,036^{*}$ \\
\hline & Napkitörés & 166 & 1,590 & 0,051 & & \\
\hline \multirow{2}{*}{$\begin{array}{l}\text { Női öngyilkosság } \\
\text { aránya (normált) }\end{array}$} & Nincs napkitörés & 12618 & 0,520 & 0,003 & $-2,773$ & $0,006^{* *}$ \\
\hline & Napkitörés & 166 & 0,599 & 0,031 & & \\
\hline \multirow{2}{*}{$\begin{array}{l}\text { Violens } \\
\text { öngyilkosság } \\
\text { aránya (normált) }\end{array}$} & Nincs napkitörés & 9714 & 0,747 & 0,003 & $-1,27$ & 0,204 \\
\hline & Napkitörés & 148 & 0,780 & 0,025 & & \\
\hline \multirow{2}{*}{$\begin{array}{l}\text { Nem violens } \\
\text { öngyilkosság } \\
\text { aránya (normált) }\end{array}$} & Nincs napkitörés & 9714 & 0,285 & 0,002 & $-1,633$ & 0,102 \\
\hline & Napkitörés & 148 & 0,312 & 0,017 & & \\
\hline \multirow{2}{*}{$\begin{array}{l}\text { Öngyilkosság } \\
\text { aránya (detrendelt } \\
\text { és deszezonalizált) }\end{array}$} & Nincs napkitörés & 12618 & 0,988 & 0,002 & $-1,269$ & 0,206 \\
\hline & Napkitörés & 166 & 1,010 & 0,017 & & \\
\hline \multirow{2}{*}{$\begin{array}{l}\text { Férfi öngyilkosság } \\
\text { aránya (detrendelt } \\
\text { és deszezonalizált) }\end{array}$} & Nincs napkitörés & 12618 & 0,984 & 0,003 & $-1,354$ & 0,177 \\
\hline & Napkitörés & 166 & 1,011 & 0,020 & & \\
\hline \multirow{2}{*}{$\begin{array}{l}\text { Női öngyilkosság } \\
\text { aránya (detrendelt } \\
\text { és deszezonalizált) }\end{array}$} & Nincs napkitörés & 12613 & 0,953 & 0,005 & $-0,517$ & 0,605 \\
\hline & Napkitörés & 166 & 0,973 & 0,037 & & \\
\hline \multirow{2}{*}{$\begin{array}{l}\text { Violens } \\
\text { öngyilkosság } \\
\text { aránya (detrendelt } \\
\text { és deszezonalizált) }\end{array}$} & Nincs napkitörés & 9714 & 0,985 & 0,003 & $-1,095$ & 0,275 \\
\hline & Napkitörés & 148 & 1,008 & 0,020 & & \\
\hline \multirow{2}{*}{$\begin{array}{l}\text { Nem violens } \\
\text { öngyilkosság } \\
\text { aránya (detrendelt } \\
\text { és deszezonalizált) }\end{array}$} & Nincs napkitörés & 9709 & 0,954 & 0,005 & $-0,731$ & 0,465 \\
\hline & Napkitörés & 148 & 0,984 & 0,039 & & \\
\hline
\end{tabular}

Megjegyzés: * $\mathrm{p}<0,05 ;$ ** $\mathrm{p}<0,01$. A szignifikáns eredményeket félkövér betúvel emeltük ki. 
Azokban a modellekben, ahol leszúkítettük a nagyobb (M/X) napkitöréseket a legintenzívebb napra, a fenti táblázatban látható összefüggések elmosódtak, mindössze a normált női adatok voltak szignifikánsak 5 százalékos szinten (a rang átlagoknál azonban ez az összefüggés sem volt szignifikáns). A detrendelt és deszezonalizált női idősor esetében ez az összefüggés továbbra sem volt azonosítható (lásd Függelék, F5. táblázat).

\subsection{Mágneses vihar}

A mágneses viharok napjainak vizsgálata hasonló eredményt mutatott, mint amit az intenzívebb napkitörések kapcsán kaptunk (3. táblázat). Az alap normált mutatók a nem violens elkövetési módot leszámítva 1 százalékos szinten szignifikánsak voltak, tehát azokon a napokon, amikor volt mágneses vihar (az Ap-index nagyobb volt mint 39), szignifikánsan több volt az öngyilkos (a férfiaknál és a nóknél is, valamint a violens elkövetés is gyakoribb volt). A rangátlagok vizsgálata ugyanezt az eredményt hozta.

Az eredményeket azonban ismét árnyalja a detrendelt és deszezonalizált idősor, ahol a fenti összefüggések már nem rajzoldónak ki, sőt ellenkezőleg, a nem violens elkövetési mód ritkább volt a mágneses viharos napokon (5 százalékos szinten volt szignifikáns ez az összefüggés, ami a rangátlagok esetében is megfigyelhetó volt).

Ha a két nappal kiterjesztett hatását is vizsgáljuk a mágneses viharoknak, az eredményeink nem változnak. A nem violens elkövetési módot leszámítva a normált mutatók szignifikáns összefüggést mutattak, a detrendelt és deszezonalizált mutatók viszont nem (lásd Függelék, F6. táblázat). Azok a modellek, ahol az erósebb mágneses viharokat teszteltük (az Ap-index > 100) viszont egyik változó mentén sem mutattak szignifikáns összefüggést (lásd Függelék, F7. és F8. táblázat). Utóbbi következhet abból is, hogy az erős mágneses viharok jóval kevesebb nap jelentkeztek, ezért a kisebb elemszám miatt csak statisztikailag erősebb összefüggés tudott volna megjelenni.

\section{Megbeszélés}

Tanulmányunkban azt a célt túztük ki, hogy megvizsgáljuk az öngyilkosságok alakulását a nap- és holdtevékenységek egyes kitüntetett periódusaiban. Munkánkban a teliholdra, a napkitörésekre és a mágneses viharokra koncentráltunk, és ezek együtt járását vizsgáltuk az öngyilkosságra a teljes lakosság szintjén, férfi-női bontásban, valamint a violens, illetve nem violens elkövetés esetében. Az eredményeink összességében felemásak. 
3. táblázat. Az öngyilkossági mutatók alakulása a mágneses viharok napjain (Ap-index > 39) - t-próba

\begin{tabular}{|c|c|c|c|c|c|c|}
\hline & & $\begin{array}{l}\text { Eset- } \\
\text { szám }\end{array}$ & Átlag & $\begin{array}{l}\text { Standard } \\
\text { hiba }\end{array}$ & t-érték & $\mathrm{p}$ \\
\hline \multirow{2}{*}{$\begin{array}{l}\text { Öngyilkosság aránya } \\
\text { (normált) }\end{array}$} & Nem & 11862 & 0,987 & 0,004 & $-3,962$ & $<0,001^{* * *}$ \\
\hline & Igen & 588 & 1,056 & 0,017 & & \\
\hline \multirow{2}{*}{$\begin{array}{l}\text { Férfi öngyilkosság } \\
\text { aránya (normált) }\end{array}$} & Nem & 11862 & 1,487 & 0,006 & $-3,479$ & $0,001^{* *}$ \\
\hline & Igen & 588 & 1,585 & 0,028 & & \\
\hline \multirow{2}{*}{$\begin{array}{l}\text { Női öngyilkosság } \\
\text { aránya (normált) }\end{array}$} & $\mathrm{Nem}$ & 11862 & 0,525 & 0,003 & $-2,65$ & $0,008^{\star *}$ \\
\hline & Igen & 588 & 0,566 & 0,015 & & \\
\hline \multirow{2}{*}{$\begin{array}{l}\text { Violens öngyilkosság } \\
\text { aránya (normált) }\end{array}$} & $\mathrm{Nem}$ & 9343 & 0,745 & 0,003 & $-2,961$ & $0,003^{* *}$ \\
\hline & Igen & 519 & 0,787 & 0,014 & & \\
\hline \multirow{2}{*}{$\begin{array}{l}\text { Nem violens } \\
\text { öngyilkosság aránya } \\
\text { (normált) }\end{array}$} & Nem & 9343 & 0,286 & 0,002 & 0,494 & 0,621 \\
\hline & Igen & 519 & 0,282 & 0,009 & & \\
\hline \multirow{2}{*}{$\begin{array}{l}\text { Öngyilkosság aránya } \\
\text { (detrendelt és } \\
\text { deszezonalizált) }\end{array}$} & Nem & 11862 & 0,989 & 0,002 & 1,339 & 0,181 \\
\hline & Igen & 588 & 0,976 & 0,010 & & \\
\hline \multirow{2}{*}{$\begin{array}{l}\text { Férfi öngyilkosság } \\
\text { aránya (detrendelt } \\
\text { és deszezonalizált) }\end{array}$} & Nem & 11862 & 0,985 & 0,003 & 0,83 & 0,407 \\
\hline & Igen & 588 & 0,976 & 0,011 & & \\
\hline \multirow{2}{*}{$\begin{array}{l}\text { Női öngyilkosság } \\
\text { aránya (detrendelt és } \\
\text { deszezonalizált) }\end{array}$} & Nem & 11857 & 0,954 & 0,005 & 0,617 & 0,537 \\
\hline & Igen & 588 & 0,942 & 0,019 & & \\
\hline \multirow{2}{*}{$\begin{array}{l}\text { Violens öngyilkosság } \\
\text { aránya (detrendelt } \\
\text { és deszezonalizált) }\end{array}$} & Nem & 9343 & 0,985 & 0,003 & $-0,702$ & 0,483 \\
\hline & Igen & 519 & 0,994 & 0,012 & & \\
\hline \multirow{2}{*}{$\begin{array}{l}\text { Nem violens } \\
\text { öngyilkosság aránya } \\
\text { (detrendelt és } \\
\text { deszezonalizált) }\end{array}$} & Nem & 9339 & 0,956 & 0,005 & 2,011 & 0,044 \\
\hline & Igen & 518 & 0,911 & 0,022 & & \\
\hline
\end{tabular}

Megjegyzés: ** $\mathrm{p}<0,01 ;{ }^{* * *} \mathrm{p}<0,001$.

A szignifikáns eredményeket félkövér betúvel emeltük ki. 
A telihold esetében inkább arra mutatnak a számításaink, hogy nincs statisztikai együtt járás a két jelenség között. Egyedül a nők esetében találtunk szignifikáns összefüggést, de ez nem állt meg 1 százalékos szinten, és a robusztusabb számítási módszer sem támasztotta alá az eredményt. Ezek az eredmények megerősítik a legtöbb szakirodalom alapján megerősített függetlenségét a holdhatásnak és az öngyilkosságnak (Biermann és mtsai, 2005; Voracek és mtsai, 2008).

A napkitörések kapcsán kevésbé egyértelmú a kép. Az mindenképpen feltételezhető az adatok alapján, hogy a gyengébb erejú napkitöréseknek nincs összefüggése az öngyilkosságokkal. A nagyobb (M/X) erősségú napkitörések viszont átlagosan magasabb öngyilkossági arányszámokkal jártak együtt, mind a teljes sokaságban, mind a nők és a férfiak között. A teljes sokaságban és a nők esetében 1 százalékos szinten is megállt ez az összefüggés. Ez az összefüggés párhuzamba állítható az ausztrál adatokon végzett vizsgálatokkal, ahol hasonló eredményre jutottak a kutatók (Berk, Dodd, \& Henry, 2006). Az eredményeket azonban árnyalja, hogy ha leszúkítettük az elemzést a legintenzívebb napra, akkor már csak a nők esetében állt meg az összefüggés (5 százalékos szinten), a robusztusabb detrendelt és deszezonalizált mutatók pedig egyik esetben sem kapcsolódtak össze szignifikánsan a napkitörésekkel. A mágneses viharok elemzése hasonlóan konfúz eredményekhez vezetett. A nem violens elkövetési formát leszámítva a normált öngyilkossági mutatók minden változó mentén magasabbak voltak azokon a napokon, amikor volt mágneses vihar, szemben azokkal a napokkal, amikor nem. Ez az összefüggés akkor is megmaradt, ha elnyújtottuk a mágneses viharok hatását 2 nappal. Azonban az intenzívebb mágneses viharokra leszúkített elemzés, valamint az összes olyan számítás, ahol a detrendelt és deszezonalizált adatsorokat használtuk fel, nem mutatott ki semmilyen összefüggést.

Ezek az eredmények természetesen nem jelentik azt, hogy nincs összefüggés, hiszen a felhasznált többlépcsős szezonális dekompozíció óhatatlanul adatveszteséggel is jár, ami eltüntethet egyébként szignifikáns (de nem túl erős) összefüggéseket. Azonban a szignifikáns összefüggéseket sem szabad túlértékelni, hiszen az ökológia modelleknek már önmagukban igen nagy bizonytalansága van, oksági összefüggések megállapítására nem is alkalmasak.

A kutatás eredményeinek kiértékelésekor fontos figyelembe venni milyen korlátokkal kell számolni az értelmezés során. Az előző bekezdésben már jeleztük, hogy az ökológia elemzések nem alkalmasak oksági következtetések levonására. Ezt kiegészíthetjük azzal is, hogy ilyen aggregált elemzések során a mikro szintú környezet és maga az individuum egyáltalán nem jelenik meg, ami tovább rontja az eredmények érvényességét. Szintén erős korlátnak gondoljuk azt, hogy viszonylag ritka eseményeket vizsgá- 
lunk, erős napkitörés vagy mágneses vihar nem túl gyakori jelenség. Bár a teljes időperiódus sok napot fed le, a vizsgálati szempontból fontos napok viszonylag ritkák. Így a becsléseink mellé széles konfidencia intervallumot kellett rendelni.

Az eredményeink a jelzett dilemmák ellenére is érdekesek és továbbgondolásra érdemesek. A holdhatás kapcsán a korábbi szakirodalmi eredményekhez hasonlóan mi is azon a véleményen vagyunk, hogy nincs statisztikai összefüggés. A különböző naptevékenységek és az öngyilkosság együtt járását azonban érdemes lenne tovább vizsgálni szofisztikáltabb statisztikai módszerekkel.

\section{Irodalomjegyzék}

Bartels, J., Heck, N.A., \& Johnston, H.F. (1939). The three hour range index measuring geomagnetic activity. Terrestrial Magnetism and Atmospheric Electricity, 44(4), 411-454.

Belleville, G., Foldes-Busque, G., Dixon, M., Marquis-Pelletier, É., Barbeau, S., Poitras, J., et al. (2013). Impact of seasonal and lunar cycles on psychological symptoms in the ED: an empirical investigation of widely spread beliefs. General hospital psychiatry, 35(2), 192-194.

Berk, M., Dodd, S., \& Henry, M. (2006). Do ambient electromagnetic fields affect behaviour? A demonstration of the relationship between geomagnetic storm activity and suicide. Bioelectromagnetics, 27(2), 151-155.

Biermann, T., Estel, D., Sperling, W., Bleich, S., Kornhuber, J., \& Reulbach, U. (2005). Influence of lunar phases on suicide: the end of a myth? A population based study. Chronobiology International, 22(6), 1137-1143.

Boor, M. (1981). Effects of United States presidential elections on suicide and other cases of death. American Sociological Review, 46(5), 616-618.

Bozsonyi, K., Osvath, P., Fekete, S., \& Bálint, L. (2015). The effects of significant international sports events on Hungarian suicide rates. Crisis, 2015. November 17:1-7. [Epub ahead of print]

Grigoryev, P., Rozanov, V., Vaiserman, A., \& Vladimirskiy, B. (2009). Heliogeophysical factors as possible triggers of suicide terroristic acts. Health, 1(4), 294-297.

Jones, P.K., \& Jones, S.L. (1977). Lunar Association with suicide. Suicide and life-threatening Behavior, 7(1), 31-39.

Hunyadi, L., \& Vita, L. (2002). Statisztika közgazdászoknak. Központi Statisztikai Hivatal, Budapest

Kildahl, K.J.N. (1980). Solar activity reports. In: R.F. Donnelly (Ed.), Solar-terrestrial predictions proceedings. Vol. 3. (166). Michigan: University of Michigan Library

Lester, D., Brockopp, G.W., \& Priebe, K. (1969). Association between a full moon and completed suicide. Psychological Reports, 25(2), 598-598.

Maldonado, G., \& Kraus, J.F. (1991). Variation in suicide occurrence by time of day, day of the week, month, and lunar phase. Suicide and Life-Threatening Behavior, 21(2), 174-187.

Martin, S.J., Kelly, I.W., \& Saklofske, D.H. (1992). Suicide and lunar cycles: a critical review over 28 years. Psychological Reports, 71(3), 787-795.

Mathew, V.M., Lindesay, J., Shanmuganathan, N., \& Eapen, V. (1991). Attempted suicide and the lunar cycle. Psychological Reports, 68(3), 927-930.

Michelson, L., Wilson, J., \& Michelson, J. (1979). Investigation of periodicity in crisis intervention calls over an eight-year span. Psychological Reports, 45(2), 420-422. 
Partonen, T., Haukka, J., Nevanlinna, H., \& Lönnqvist, J. (2004). Analysis of the seasonal pattern in suicide. Journal of Affective Disorders, 81(2), 133-139.

Petridou, E., Papadopoulos, F.C., Frangakis, C.E., Skalkidou, A., \& Trichopoulos, D. (2002). A role of sunshine in the triggering of suicide. Epidemiology, 13(1), 106-109.

Pokorny, A. D. (1964). Moon phases, suicide, and homicide. American Journal of Psychiatry, 121(1), 66-67.

Rotton, J., Kelly, I.W., \& Frey, J. (1983). Geophysical variables and behavior: X. Detecting lunar periodicities: something old, new, borrowed, and true. Psychological Reports, 52(1), 111-116.

Taylor, L.J., \& Diespecker, D.D. (1972). Moon phases and suicide attempts in Australia. Psychological Reports, 31(1), 110.

Voracek, M., Loibl, L.M., Kapusta, N.D., Niederkrotenthaler, T., Dervic, K., \& Sonneck, G. (2008). Not carried away by a moonlight shadow: no evidence for associations between suicide occurrence and lunar phase among more than 65,000 suicide cases in Austria, 1970-2006. Wiener KlinischeWochenschrift, 120(11-12), 343-349.

Wasserman, I.M. (1983) Political business cycles, presidential elections, and suicide and mortality patterns. American Sociological Review, 48(5), 711-720.

Zonda, T. (2006). Öngyilkosság, statisztika, társadalom. Kairosz.

Zonda, T., Bozsonyi, K., \& Veres, E. (2005). Seasonal fluctuation of suicide in Hungary between 1970-2000. Archives of Suicide Research, 9(1), 77-85.

Zonda, T., Bozsonyi, K., Kmetty, Z., Veres, E., \& Lester, D. (2016). The birthday blues: a study of a large Hungarian sample (1970-2002). OMEGA - Journal of Death and Dying, 73(1). 87-94.

Zonda, T., Kmetty, Z., Lester, D., \& Tóth, M.D. (2015). Effects of parliamentary elections on suicide rates in Hungary. Crisis, 2015. Február 23:1-4. [Epub ahead of print]

\section{A szerzók munkamegosztása}

Kmetty Zoltán: hipotézisek felállítása, statisztikai modellek lefuttatása, kiértékelésük, kézirat megszövegezése. Bozsonyi Károly: hipotézisek felállítása, statisztikai eredmények kiértékelése, szöveggondozás. Tomasovszky Álmos: adatgyújtés, szakirodalom-gyứjtés, szöveggondozás.

\section{Nyilatkozat érdekütközésról}

A szerzők ezúton kijelentik, hogy esetükben nem állnak fenn érdekütközések. 


\section{Függelék}

F1. táblázat. Az öngyilkossági mutatók alakulása a telihold \pm 2 napon - t-próba

\begin{tabular}{|c|c|c|c|c|c|c|}
\hline & & $\begin{array}{l}\text { Eset- } \\
\text { szám }\end{array}$ & Átlag & $\begin{array}{l}\text { Standard } \\
\text { hiba }\end{array}$ & t-érték & $\mathrm{p}$ \\
\hline \multirow{2}{*}{$\begin{array}{l}\text { Öngyilkosság aránya } \\
\text { (normált) }\end{array}$} & Nincs telihold & 10619 & 0,985 & 0,004 & 1,359 & 0,174 \\
\hline & Telihold & 2165 & 0,972 & 0,009 & & \\
\hline \multirow{2}{*}{$\begin{array}{l}\text { Férfi öngyilkosság } \\
\text { aránya (normált) }\end{array}$} & Nincs telihold & 10619 & 1,484 & 0,006 & 0,682 & 0,495 \\
\hline & Telihold & 2165 & 1,473 & 0,014 & & \\
\hline \multirow{2}{*}{$\begin{array}{l}\text { Női öngyilkosság } \\
\text { aránya (normált) }\end{array}$} & Nincs telihold & 10619 & 0,524 & 0,004 & 1,826 & $0,068^{+}$ \\
\hline & Telihold & 2165 & 0,508 & 0,008 & & \\
\hline \multirow{2}{*}{$\begin{array}{l}\text { Violens öngyilkosság } \\
\text { aránya (normált) }\end{array}$} & Nincs telihold & 8192 & 0,749 & 0,003 & 1,437 & 0,151 \\
\hline & Telihold & 1670 & 0,737 & 0,008 & & \\
\hline \multirow{2}{*}{$\begin{array}{l}\text { Nem violens } \\
\text { öngyilkosság aránya } \\
\text { (normált) }\end{array}$} & Nincs telihold & 8192 & 0,287 & 0,002 & 1,373 & 0,170 \\
\hline & Telihold & 1670 & 0,280 & 0,005 & & \\
\hline \multirow{2}{*}{$\begin{array}{l}\text { Öngyilkosság aránya } \\
\text { (detrendelt és } \\
\text { deszezonalizált) }\end{array}$} & Nincs telihold & 10619 & 0,989 & 0,002 & 0,155 & 0,877 \\
\hline & Telihold & 2165 & 0,988 & 0,005 & & \\
\hline \multirow{2}{*}{$\begin{array}{l}\text { Férfi öngyilkosság } \\
\text { aránya (detrendelt } \\
\text { és deszezonalizált) }\end{array}$} & Nincs telihold & 10619 & 0,985 & 0,003 & 0,107 & 0,915 \\
\hline & Telihold & 2165 & 0,984 & 0,006 & & \\
\hline \multirow{2}{*}{$\begin{array}{l}\text { Női öngyilkosság } \\
\text { aránya (detrendelt } \\
\text { és deszezonalizált) }\end{array}$} & Nincs telihold & 10616 & 0,955 & 0,005 & 0,742 & 0,458 \\
\hline & Telihold & 2163 & 0,946 & 0,011 & & \\
\hline \multirow{2}{*}{$\begin{array}{l}\text { Violens öngyilkosság } \\
\text { aránya (detrendelt } \\
\text { és deszezonalizált) }\end{array}$} & Nincs telihold & 8192 & 0,986 & 0,003 & 0,333 & 0,739 \\
\hline & Telihold & 1670 & 0,984 & 0,007 & & \\
\hline \multirow{2}{*}{$\begin{array}{l}\text { Nem violens } \\
\text { öngyilkosság aránya } \\
\text { (detrendelt és } \\
\text { deszezonalizált) }\end{array}$} & Nincs telihold & 8190 & 0,955 & 0,006 & 0,358 & 0,721 \\
\hline & Telihold & 1667 & 0,950 & 0,013 & & \\
\hline
\end{tabular}

Megjegyzés: ${ }^{+} \mathrm{p}<0,10$. 
F2. táblázat. Az öngyilkossági mutatók alakulása újhold/telihold/köztes időszak bontásban - ANOVA vizsgálat F próbával

\begin{tabular}{|l|c|c|}
\hline & F-érték & $\mathrm{p}$ \\
\hline Öngyilkosság aránya (normált) & 1,542 & 0,214 \\
\hline Férfi öngyilkosság aránya (normált) & 0,575 & 0,563 \\
\hline Nói öngyilkosság aránya (normált) & 2,212 & 0,110 \\
\hline Violens öngyilkosság aránya (normált) & 1,034 & 0,356 \\
\hline Nem violens öngyilkosság aránya (normált) & 1,194 & 0,303 \\
\hline & & \\
\hline Öngyilkosság aránya (detrendelt és deszezonalizált) & 0,813 & 0,443 \\
\hline Férfi öngyilkosság aránya (detrendelt és deszezonalizált) & 0,486 & 0,615 \\
\hline Nói öngyilkosság aránya (detrendelt és deszezonalizált) & 0,610 & 0,543 \\
\hline Violens öngyilkosság aránya (detrendelt és deszezonalizált) & 0,200 & 0,819 \\
\hline Nem violens öngyilkosság aránya (detrendelt és deszezonalizált) & 0,337 & 0,714 \\
\hline
\end{tabular}

F3. táblázat. Az öngyilkossági mutatók alakulása a napkitörésekkor (teljes napkitörés ciklus, minden erősség) - t-próba

\begin{tabular}{|c|c|c|c|c|c|c|}
\hline & & $\begin{array}{l}\text { Eset- } \\
\text { szám }\end{array}$ & Átlag & $\begin{array}{l}\text { Stan- } \\
\text { dard } \\
\text { hiba }\end{array}$ & t-érték & $\mathrm{p}$ \\
\hline \multirow{2}{*}{$\begin{array}{l}\text { Öngyilkosság aránya } \\
\text { (normált) }\end{array}$} & Nincs napkitörés & 12305 & 0,983 & 0,004 & 0,132 & 0,895 \\
\hline & Napkitörés & 479 & 0,980 & 0,017 & & \\
\hline \multirow{2}{*}{$\begin{array}{l}\text { Férfi öngyilkosság } \\
\text { aránya (normált) }\end{array}$} & Nincs napkitörés & 12305 & 1,482 & 0,006 & $-0,595$ & 0,552 \\
\hline & Napkitörés & 479 & 1,500 & 0,028 & & \\
\hline \multirow{2}{*}{$\begin{array}{l}\text { Női öngyilkosság } \\
\text { aránya (normált) }\end{array}$} & Nincs napkitörés & 12305 & 0,522 & 0,003 & 1,097 & 0,273 \\
\hline & Napkitörés & 479 & 0,503 & 0,017 & & \\
\hline \multirow{2}{*}{$\begin{array}{l}\text { Violens öngyilkosság } \\
\text { aránya (normált) }\end{array}$} & Nincs napkitörés & 9556 & 0,747 & 0,003 & $-1,227$ & 0,220 \\
\hline & Napkitörés & 306 & 0,769 & 0,017 & & \\
\hline \multirow{2}{*}{$\begin{array}{l}\text { Nem violens } \\
\text { öngyilkosság aránya } \\
\text { (normált) }\end{array}$} & Nincs napkitörés & 9556 & 0,286 & 0,002 & $-0,066$ & 0,948 \\
\hline & Napkitörés & 306 & 0,286 & 0,011 & & \\
\hline
\end{tabular}




\begin{tabular}{|l|l|c|c|c|c|c|}
\hline & & $\begin{array}{c}\text { Eset- } \\
\text { szám }\end{array}$ & Átlag & $\begin{array}{c}\text { Stan- } \\
\text { dard } \\
\text { hiba }\end{array}$ & t-érték & $\mathrm{p}$ \\
\hline $\begin{array}{l}\text { Öngyilkosság aránya } \\
\text { (detrendelt és } \\
\text { deszezonalizált) }\end{array}$ & Nincs napkitörés & 12305 & 0,988 & 0,002 & $-1,242$ & 0,214 \\
\cline { 2 - 7 } & Napkitörés & 479 & 1,003 & 0,011 & & \\
\hline $\begin{array}{l}\text { Férfi öngyilkosság } \\
\text { aránya (detrendelt } \\
\text { és deszezonalizált) }\end{array}$ & Nincs napkitörés & 12305 & 0,984 & 0,003 & $-1,254$ & 0,210 \\
\cline { 2 - 8 } & Napkitörés & 479 & 1,001 & 0,013 & & \\
\hline $\begin{array}{l}\text { Női öngyilkosság } \\
\text { aránya (detrendelt } \\
\text { és deszezonalizált) }\end{array}$ & Nincs napkitörés & 12300 & 0,953 & 0,005 & $-0,048$ & 0,961 \\
\cline { 2 - 8 } & Napkitörés & 479 & 0,954 & 0,023 & & \\
\hline $\begin{array}{l}\text { Violens öngyilkosság } \\
\text { aránya (detrendelt } \\
\text { és deszezonalizált) }\end{array}$ & Nincs napkitörés & 9556 & 0,985 & 0,003 & $-1,632$ & 0,103 \\
\cline { 2 - 8 } & Napkitörés & 306 & 1,012 & 0,016 & & \\
\hline $\begin{array}{l}\text { Nem violens } \\
\text { öngyilkosság aránya } \\
\text { (detrendelt } \\
\text { és deszezonalizált) }\end{array}$ & Nincs napkitörés & 9551 & 0,953 & 0,005 & $-0,59$ & 0,555 \\
\cline { 2 - 7 } & Napkitörés & 306 & 0,971 & 0,028 & & \\
\hline
\end{tabular}

F4. táblázat. Az öngyilkossági mutatók alakulása a napkitörésekkor (napkitörés legintenzívebb napja, minden erősség) - t-próba

\begin{tabular}{|c|c|c|c|c|c|c|}
\hline & & $\begin{array}{l}\text { Eset- } \\
\text { szám }\end{array}$ & Átlag & $\begin{array}{l}\text { Stan- } \\
\text { dard } \\
\text { hiba }\end{array}$ & t-érték & $\mathrm{p}$ \\
\hline \multirow{2}{*}{$\begin{array}{l}\text { Öngyilkosság aránya } \\
\text { (normált) }\end{array}$} & Nincs napkitörés & 12561 & 0,982 & 0,004 & $-1,665$ & $0,097^{+}$ \\
\hline & Napkitörés & 223 & 1,024 & 0,025 & & \\
\hline \multirow{2}{*}{$\begin{array}{l}\text { Férfi öngyilkosság } \\
\text { aránya (normált) }\end{array}$} & Nincs napkitörés & 12561 & 1,481 & 0,006 & $-1,292$ & 0,196 \\
\hline & Napkitörés & 223 & 1,539 & 0,041 & & \\
\hline \multirow{2}{*}{$\begin{array}{l}\text { Női öngyilkosság } \\
\text { aránya (normált) }\end{array}$} & Nincs napkitörés & 12561 & 0,521 & 0,003 & $-1,152$ & 0,249 \\
\hline & Napkitörés & 223 & 0,549 & 0,026 & & \\
\hline \multirow{2}{*}{$\begin{array}{l}\text { Violens öngyilkosság } \\
\text { aránya (normált) }\end{array}$} & Nincs napkitörés & 9663 & 0,747 & 0,003 & $-0,854$ & 0,393 \\
\hline & Napkitörés & 199 & 0,766 & 0,021 & & \\
\hline \multirow{2}{*}{$\begin{array}{l}\text { Nem violens } \\
\text { öngyilkosság aránya } \\
\text { (normált) }\end{array}$} & Nincs napkitörés & 9663 & 0,286 & 0,002 & 1,109 & 0,268 \\
\hline & Napkitörés & 199 & 0,270 & 0,013 & & \\
\hline
\end{tabular}




\begin{tabular}{|c|c|c|c|c|c|c|}
\hline & & $\begin{array}{l}\text { Eset- } \\
\text { szám }\end{array}$ & Átlag & $\begin{array}{l}\text { Stan- } \\
\text { dard } \\
\text { hiba }\end{array}$ & t-érték & $\mathrm{p}$ \\
\hline \multirow{2}{*}{$\begin{array}{l}\text { Öngyilkosság aránya } \\
\text { (detrendelt és } \\
\text { deszezonalizált) }\end{array}$} & Nincs napkitörés & 12561 & 0,988 & 0,002 & $-0,711$ & 0,478 \\
\hline & Napkitörés & 223 & 0,999 & 0,015 & & \\
\hline \multirow{2}{*}{$\begin{array}{l}\text { Férfi öngyilkosság } \\
\text { aránya (detrendelt } \\
\text { és deszezonalizált) }\end{array}$} & Nincs napkitörés & 12561 & 0,984 & 0,003 & $-0,612$ & 0,541 \\
\hline & Napkitörés & 223 & 0,997 & 0,018 & & \\
\hline \multirow{2}{*}{$\begin{array}{l}\text { Női öngyilkosság } \\
\text { aránya (detrendelt } \\
\text { és deszezonalizált) }\end{array}$} & Nincs napkitörés & 12556 & 0,953 & 0,005 & 0,002 & 0,999 \\
\hline & Napkitörés & 223 & 0,953 & 0,030 & & \\
\hline \multirow{2}{*}{$\begin{array}{l}\text { Violens öngyilkosság } \\
\text { aránya (detrendelt } \\
\text { és deszezonalizált) }\end{array}$} & Nincs napkitörés & 9663 & 0,985 & 0,003 & $-1,258$ & 0,208 \\
\hline & Napkitörés & 199 & 1,011 & 0,018 & & \\
\hline \multirow{2}{*}{$\begin{array}{l}\text { Nem violens } \\
\text { öngyilkosság aránya } \\
\text { (detrendelt } \\
\text { és deszezonalizált) }\end{array}$} & Nincs napkitörés & 9658 & 0,954 & 0,005 & 0,213 & 0,831 \\
\hline & Napkitörés & 199 & 0,946 & 0,034 & & \\
\hline
\end{tabular}

Megjegyzés: ${ }^{+} \mathrm{p}<0,10$.

F5. táblázat. Az öngyilkossági mutatók alakulása a napkitörésekkor (napkitörés legintenzívebb napja, $\mathrm{M}$ és $\mathrm{X}$ erősség) - t-próba

\begin{tabular}{|c|c|c|c|c|c|c|}
\hline & & $\begin{array}{l}\text { Eset- } \\
\text { szám }\end{array}$ & Átlag & $\begin{array}{l}\text { Stan- } \\
\text { dard } \\
\text { hiba }\end{array}$ & t-érték & $p$ \\
\hline \multirow{2}{*}{$\begin{array}{l}\text { Öngyilkosság aránya } \\
\text { (normált) }\end{array}$} & Nincs napkitörés & 12694 & 0,982 & 0,004 & $-1,21$ & 0,226 \\
\hline & Napkitörés & 90 & 1,035 & 0,044 & & \\
\hline \multirow{2}{*}{$\begin{array}{l}\text { Férfi öngyilkosság } \\
\text { aránya (normált) }\end{array}$} & Nincs napkitörés & 12694 & 1,482 & 0,006 & $-0,359$ & 0,720 \\
\hline & Napkitörés & 90 & 1,507 & 0,065 & & \\
\hline \multirow{2}{*}{$\begin{array}{l}\text { Női öngyilkosság } \\
\text { aránya (normált) }\end{array}$} & Nincs napkitörés & 12694 & 0,521 & 0,003 & $-2,014$ & $0,044^{*}$ \\
\hline & Napkitörés & 90 & 0,598 & 0,045 & & \\
\hline \multirow{2}{*}{$\begin{array}{l}\text { Violens öngyilkosság } \\
\text { aránya (normált) }\end{array}$} & Nincs napkitörés & 9781 & 0,747 & 0,003 & $-0,181$ & 0,856 \\
\hline & Napkitörés & 81 & 0,754 & 0,034 & & \\
\hline \multirow{2}{*}{$\begin{array}{l}\text { Nem violens } \\
\text { öngyilkosság aránya } \\
\text { (normált) }\end{array}$} & Nincs napkitörés & 9781 & 0,286 & 0,002 & $-0,332$ & 0,740 \\
\hline & Napkitörés & 81 & 0,293 & 0,020 & & \\
\hline
\end{tabular}




\begin{tabular}{|l|l|c|c|c|c|c|}
\hline & & $\begin{array}{c}\text { Eset- } \\
\text { szám }\end{array}$ & Átlag & $\begin{array}{c}\text { Stan- } \\
\text { dard } \\
\text { hiba }\end{array}$ & t-érték & $\mathrm{p}$ \\
\hline $\begin{array}{l}\text { Öngyilkosság aránya } \\
\text { (detrendelt és } \\
\text { deszezonalizált) }\end{array}$ & Nincs napkitörés & 12694 & 0,989 & 0,002 & $-0,166$ & 0,868 \\
\cline { 2 - 8 } & Napkitörés & 90 & 0,992 & 0,021 & & \\
\hline $\begin{array}{l}\text { Férfi öngyilkosság } \\
\text { aránya (detrendelt } \\
\text { és deszezonalizált) }\end{array}$ & Nincs napkitörés & 12694 & 0,985 & 0,003 & 0,014 & 0,989 \\
\cline { 2 - 8 } & Napkitörés & 90 & 0,984 & 0,024 & & \\
\hline $\begin{array}{l}\text { Nói öngyilkosság } \\
\text { aránya (detrendelt } \\
\text { és deszezonalizált) }\end{array}$ & Nincs napkitörés & 12689 & 0,953 & 0,004 & $-0,528$ & 0,597 \\
\cline { 2 - 8 } & Napkitörés & 90 & 0,981 & 0,046 & & \\
\hline $\begin{array}{l}\text { Violens öngyilkosság } \\
\text { aránya (detrendelt } \\
\text { és deszezonalizált) }\end{array}$ & Nincs napkitörés & 9781 & 0,986 & 0,003 & $-0,252$ & 0,802 \\
\cline { 2 - 8 } & Napkitörés & 81 & 0,992 & 0,024 & & \\
\hline $\begin{array}{l}\text { Nem violens } \\
\text { öngyilkosság aránya } \\
\text { (detrendelt és } \\
\text { deszezonalizált) }\end{array}$ & Nincs napkitörés & 9776 & 0,954 & 0,005 & $-0,371$ & 0,711 \\
\cline { 2 - 7 } & Napkitörés & 81 & 0,975 & 0,048 & & \\
\hline
\end{tabular}

Megjegyzés: * p<0,05. A szignifikáns eredményeket félkövér betúvel emeltük ki.

F6. táblázat. Az öngyilkossági mutatók alakulása a mágneses viharok napjain és az azt követő 2 napon (Ap-index > 39) - t-próba

\begin{tabular}{|c|c|c|c|c|c|c|}
\hline & & $\begin{array}{l}\text { Eset- } \\
\text { szám }\end{array}$ & Átlag & $\begin{array}{l}\text { Standard } \\
\text { hiba }\end{array}$ & t érték & $\mathrm{p}$ \\
\hline \multirow{2}{*}{$\begin{array}{l}\text { Öngyilkosság aránya } \\
\text { (normált) }\end{array}$} & Nem & 11441 & 0,974 & 0,004 & $-7,078$ & $<0,001^{* * *}$ \\
\hline & Igen & 1343 & 1,058 & 0,011 & & \\
\hline \multirow{2}{*}{$\begin{array}{l}\text { Férfi öngyilkosság } \\
\text { aránya (normált) }\end{array}$} & Nem & 11441 & 1,469 & 0,006 & $-6,578$ & $<0,001^{* * *}$ \\
\hline & Igen & 1343 & 1,595 & 0,018 & & \\
\hline \multirow{2}{*}{$\begin{array}{l}\text { Női öngyilkosság } \\
\text { aránya (normált) }\end{array}$} & Nem & 11441 & 0,517 & 0,003 & $-4,15$ & $<0,001^{* * *}$ \\
\hline & Igen & 1343 & 0,560 & 0,010 & & \\
\hline \multirow{2}{*}{$\begin{array}{l}\text { Violens öngyilkosság } \\
\text { aránya (normált) }\end{array}$} & Nem & 8673 & 0,744 & 0,003 & $-3,255$ & $0,001^{* *}$ \\
\hline & Igen & 1189 & 0,775 & 0,009 & & \\
\hline \multirow{2}{*}{$\begin{array}{l}\text { Nem violens } \\
\text { öngyilkosság aránya } \\
\text { (normált) }\end{array}$} & Nem & 8673 & 0,285 & 0,002 & $-0,673$ & 0,501 \\
\hline & Igen & 1189 & 0,289 & 0,006 & & \\
\hline
\end{tabular}




\begin{tabular}{|c|c|c|c|c|c|c|}
\hline & & $\begin{array}{l}\text { Eset- } \\
\text { szám }\end{array}$ & Átlag & $\begin{array}{l}\text { Standard } \\
\text { hiba }\end{array}$ & t érték & $\mathrm{p}$ \\
\hline Öngyilkosság aránya & Nem & 11441 & 0,989 & 0,002 & 0,667 & 0,505 \\
\hline $\begin{array}{l}\text { (detrendelt és } \\
\text { deszezonalizált) }\end{array}$ & Igen & 1343 & 0,984 & 0,006 & & \\
\hline Férfi öngyilkosság & Nem & 11441 & 0,984 & 0,003 & $-0,469$ & 0,639 \\
\hline $\begin{array}{l}\text { aranya (detrendelt } \\
\text { és deszezonalizált) }\end{array}$ & Igen & 1343 & 0,988 & 0,008 & & \\
\hline Női öngyilkosság & Nem & 11438 & 0,955 & 0,005 & 1,21 & 0,227 \\
\hline $\begin{array}{l}\text { aránya (detrendelt } \\
\text { és deszezonalizált) }\end{array}$ & Igen & 1341 & 0,938 & 0,013 & & \\
\hline Violens öngyilkosság & Nem & 8673 & 0,985 & 0,003 & $-0,276$ & 0,782 \\
\hline $\begin{array}{l}\text { aránya (detrendelt } \\
\text { és deszezonalizált) }\end{array}$ & Igen & 1189 & 0,988 & 0,008 & & \\
\hline Nem violens & Nem & 8669 & 0,957 & 0,005 & 1,431 & 0,153 \\
\hline $\begin{array}{l}\text { ongyilkossag aranya } \\
\text { (detrendelt és } \\
\text { deszezonalizált) }\end{array}$ & Igen & 1188 & 0,934 & 0,014 & & \\
\hline
\end{tabular}

Megjegyzés: ** $\mathrm{p}<0,01 ;{ }^{* * *} \mathrm{p}<0,001$. A szignifikáns eredményeket félkövér betúvel emeltük ki.

F7. táblázat. Az öngyilkossági mutatók alakulása az intenzív mágneses viharok napjain (Ap-index > 100) - t-próba

\begin{tabular}{|l|l|c|c|c|c|c|}
\hline \multicolumn{2}{|c|}{} & $\begin{array}{c}\text { Eset- } \\
\text { szám }\end{array}$ & Átlag & $\begin{array}{c}\text { Standard } \\
\text { hiba }\end{array}$ & t-érték & p \\
\hline $\begin{array}{l}\text { Öngyilkosság aránya } \\
\text { (normált) }\end{array}$ & Nem & 12404 & 0,990 & 0,004 & $-1,205$ & 0,228 \\
\cline { 2 - 8 } & Igen & 46 & 1,064 & 0,052 & & \\
\hline $\begin{array}{l}\text { Férfi öngyilkosság aránya } \\
\text { (normált) }\end{array}$ & Nem & 12404 & 1,491 & 0,006 & $-1,234$ & 0,217 \\
\cline { 2 - 8 } & Igen & 46 & 1,612 & 0,082 & & \\
\hline \multirow{2}{*}{$\begin{array}{l}\text { Nói öngyilkosság aránya } \\
\text { (normált) }\end{array}$} & Nem & 12404 & 0,527 & 0,003 & $-0,564$ & 0,573 \\
\cline { 2 - 8 } & Igen & 46 & 0,557 & 0,057 & & \\
\hline $\begin{array}{l}\text { Violens öngyilkosság } \\
\text { aránya (normált) }\end{array}$ & Nem & 9825 & 0,747 & 0,003 & $-1,595$ & 0,111 \\
\cline { 2 - 8 } & Igen & 37 & 0,829 & 0,043 & & \\
\hline $\begin{array}{l}\text { Nem violens öngyilkosság } \\
\text { aránya (normált) }\end{array}$ & Nem & 9825 & 0,286 & 0,002 & $-0,102$ & 0,919 \\
\cline { 2 - 8 } & Igen & 37 & 0,289 & 0,027 & & \\
\hline & & & & & \\
\hline
\end{tabular}




\begin{tabular}{|c|c|c|c|c|c|c|}
\hline & & $\begin{array}{l}\text { Eset- } \\
\text { szám }\end{array}$ & Átlag & $\begin{array}{l}\text { Standard } \\
\text { hiba }\end{array}$ & t-érték & $p$ \\
\hline \multirow{2}{*}{$\begin{array}{l}\text { Öngyilkosság aránya } \\
\text { (detrendelt és } \\
\text { deszezonalizált) }\end{array}$} & Nem & 12404 & 0,989 & 0,002 & $-0,719$ & 0,476 \\
\hline & Igen & 46 & 1,008 & 0,028 & & \\
\hline \multirow{2}{*}{$\begin{array}{l}\text { Férfi öngyilkosság aránya } \\
\text { (detrendelt és } \\
\text { deszezonalizált) }\end{array}$} & Nem & 12404 & 0,985 & 0,003 & $-1,482$ & 0,145 \\
\hline & Igen & 46 & 1,033 & 0,033 & & \\
\hline \multirow{2}{*}{$\begin{array}{l}\text { Női öngyilkosság aránya } \\
\text { (detrendelt és } \\
\text { deszezonalizált) }\end{array}$} & Nem & 12399 & 0,954 & 0,004 & 1,134 & 0,257 \\
\hline & Igen & 46 & 0,870 & 0,067 & & \\
\hline \multirow{2}{*}{$\begin{array}{l}\text { Violens öngyilkosság } \\
\text { aránya (detrendelt } \\
\text { és deszezonalizált) }\end{array}$} & Nem & 9825 & 0,985 & 0,003 & $-1,597$ & 0,119 \\
\hline & Igen & 37 & 1,037 & 0,032 & & \\
\hline \multirow{2}{*}{$\begin{array}{l}\text { Nem violens öngyilkosság } \\
\text { aránya (detrendelt } \\
\text { és deszezonalizált) }\end{array}$} & Nem & 9820 & 0,954 & 0,005 & 0,141 & 0,888 \\
\hline & Igen & 37 & 0,942 & 0,081 & & \\
\hline
\end{tabular}

F8. táblázat. Az öngyilkossági mutatók alakulása az intenzív mágneses viharok napjain és az azt követő 2 napon (Ap-index > 100) - t-próba

\begin{tabular}{|c|c|c|c|c|c|c|}
\hline & & $\begin{array}{l}\text { Eset- } \\
\text { szám }\end{array}$ & Átlag & $\begin{array}{l}\text { Standard } \\
\text { hiba }\end{array}$ & t-érték & $\mathrm{p}$ \\
\hline \multirow{2}{*}{$\begin{array}{l}\text { Öngyilkosság aránya } \\
\text { (normált) }\end{array}$} & Nem & 12665 & 0,982 & 0,004 & $-1,334$ & 0,182 \\
\hline & Igen & 119 & 1,033 & 0,034 & & \\
\hline \multirow{2}{*}{$\begin{array}{l}\text { Férfi öngyilkosság aránya } \\
\text { (normált) }\end{array}$} & Nem & 12665 & 1,482 & 0,006 & $-0,741$ & 0,460 \\
\hline & Igen & 119 & 1,522 & 0,053 & & \\
\hline \multirow{2}{*}{$\begin{array}{l}\text { Női öngyilkosság aránya } \\
\text { (normált) }\end{array}$} & Nem & 12665 & 0,521 & 0,003 & $-1,806$ & $0,071^{+}$ \\
\hline & Igen & 119 & 0,581 & 0,034 & & \\
\hline \multirow{2}{*}{$\begin{array}{l}\text { Violens öngyilkosság } \\
\text { aránya (normált) }\end{array}$} & Nem & 9761 & 0,747 & 0,003 & $-0,989$ & 0,322 \\
\hline & Igen & 101 & 0,778 & 0,027 & & \\
\hline \multirow{2}{*}{$\begin{array}{l}\text { Nem violens öngyilkosság } \\
\text { aránya (normált) }\end{array}$} & Nem & 9761 & 0,286 & 0,002 & $-0,105$ & 0,916 \\
\hline & Igen & 101 & 0,288 & 0,018 & & \\
\hline \multirow{2}{*}{$\begin{array}{l}\text { Öngyilkosság aránya } \\
\text { (detrendelt és } \\
\text { deszezonalizált) }\end{array}$} & Nem & 12665 & 0,989 & 0,002 & 0,427 & 0,67 \\
\hline & Igen & 119 & 0,981 & 0,017 & & \\
\hline
\end{tabular}




\begin{tabular}{|c|c|c|c|c|c|c|}
\hline & & $\begin{array}{l}\text { Eset- } \\
\text { szám }\end{array}$ & Átlag & $\begin{array}{c}\text { Standard } \\
\text { hiba }\end{array}$ & t-érték & $\mathrm{p}$ \\
\hline \multirow{2}{*}{$\begin{array}{l}\text { Férfi öngyilkosság aránya } \\
\text { (detrendelt és } \\
\text { deszezonalizált) }\end{array}$} & Nem & 12665 & 0,985 & 0,003 & 0,212 & 0,833 \\
\hline & Igen & 119 & 0,980 & 0,021 & & \\
\hline \multirow{2}{*}{$\begin{array}{l}\text { Női öngyilkosság aránya } \\
\text { (detrendelt és } \\
\text { deszezonalizált) }\end{array}$} & Nem & 12660 & 0,953 & 0,004 & 0,404 & 0,686 \\
\hline & Igen & 119 & 0,934 & 0,044 & & \\
\hline \multirow{2}{*}{$\begin{array}{l}\text { Violens öngyilkosság } \\
\text { aránya (detrendelt } \\
\text { és deszezonalizált) }\end{array}$} & Nem & 9761 & 0,986 & 0,003 & 0,264 & 0,793 \\
\hline & Igen & 101 & 0,980 & 0,022 & & \\
\hline \multirow{2}{*}{$\begin{array}{l}\text { Nem violens öngyilkosság } \\
\text { aránya (detrendelt } \\
\text { és deszezonalizált) }\end{array}$} & Nem & 9756 & 0,954 & 0,005 & 0,455 & 0,649 \\
\hline & Igen & 101 & 0,931 & 0,047 & & \\
\hline
\end{tabular}

Megjegyzés: ${ }^{+} \mathrm{p}<0,10$.

\title{
Sun, Moon, stars
}

\section{The impact of moon phases, sun eruptions and geomagnetic storms to suicide}

\author{
KMETTY, ZOLTÁN - BOZSONYI, KÁROLY - TOMASOVSZKY, \\ ÁLMOS
}

Theoretical Background: The research of suicide examine the possible risk factors of suicide in a very wide aspect. Researches that examined the possible impact of lunar-cycles to suicide have been published as far back as the 60-s. The earlier works in this topic brought mixed results, but they rather strengthen the hypothesis that the full moon what these works mainly focused on, has no significant impact on suicide. The solar activities like sun eruptions and their impact to earth (like geomagnetic storms) is a less researched topic in the aspect of suicide. But the recent results showed, that there is a possible correlation between these phenomenon, although the "working mechanism" has been left blank in these works. Aim: The aim of this study is to examine the impact of moon phases, sun eruptions and geomagnetic storms to suicide. The daily time series of more than 30 years of suicide data (used in this paper) yield a unique possibility to us to examine this research question in a more detailed way compared to other works. Methods: In this paper we examine the daily normed suicide rates (12784 days) between 1976 and 2010, from the aspect of lunar cycles, sun eruptions and geomagnetic storms. In the case of suicide time series beside the normed suicide rates (based on yearly population size), the paper also examine the seasonal decomposed suicide time series (from where we removed the trend and season effects). In the case of lunar cycle we focus on the full moon, in the case of sun eruptions we examine all the measurable sun eruptions and also the strong ones $(M / X)$, and in the 
case of geomagnetic storms we distinguish the medium $(\mathrm{AP}>39)$ and strong $(\mathrm{AP}>100)$ ones. We compare the daily mean of suicide in the days of event and the days without the phenomenon, with $t$ /Welch statistic probes, and also with the "rank" types of these probes. Results: The results of the full moon part of the paper indicated that there was no correlation between moon phases and suicide (the effect was only significant in the female data, and only in the normed models). The examination of sun eruptions and geomagnetic storms showed more significant results, also in the level of whole population, and in the male and female part of it. But this effect could be caused by the correlations of season components, because the above results haven't occurred in the models based on the detrended and desesonalized time series. Conclusion: In the case of sun eruptions and geomagnetic storms it seems that it is worth to continue the researches with more complex statistical methods.

Keywords: suicide, full moon, sun eruption, geomagnetic storm, time series analysis 